\title{
Electrochemical decolorization of Rhodamine B dye: Influence of anode material, chloride concentration and current density
}

\author{
Ali Baddouh ${ }^{\mathrm{a}, \mathrm{b}}$, Guilherme Garcia Bessegato ${ }^{\mathrm{b}}$, Mohamed M. Rguiti ${ }^{\mathrm{a}}$, Brahim El Ibrahimi ${ }^{\mathrm{a}, *}$, \\ Lahcen Bazzi ${ }^{\mathrm{a}}$, Mustapha Hilali ${ }^{\mathrm{a}}$, Maria Valnice Boldrin Zanoni ${ }^{\mathrm{b}}$ \\ a Applied Chemistry-Physic Team, Faculty of Sciences, IBN ZOHR University, B.P. 8106 Cité Dakhla, Agadir, Morocco \\ ${ }^{\mathrm{b}}$ Universidade Estadual Paulista (Unesp), Instituto de Química, Araraquara. Av. Prof. Francisco Degni, 55, 14800-060, Araraquara, SP, Brazil
}

\section{A R T I C L E I N F O}

\section{Keywords:}

Degradation

Electrochemical oxidation

Rhodamine B

DSA

$\mathrm{SnO}_{2}$ electrode

\begin{abstract}
A B S T R A C T
Surface water contamination by dyes released from a variety of industries is an environmental problem of great concern. However, electrochemical oxidation is a promising alternative for water treatment. In this paper, we studied the electrochemical oxidation of Rhodamine $\mathrm{B}(\mathrm{RhB})$ dye on the $\mathrm{Ti} / \mathrm{RuO}_{2}-\mathrm{IrO}_{2}\left(\mathrm{DSA}^{\circ}\right)$ and $\mathrm{SnO} \mathrm{O}_{2}$ anodes comparing their efficiencies. The effect of some parameters, such as current density, initial $\mathrm{pH}\left(\mathrm{pH}_{0}\right)$, nature, concentration of electrolyte and temperature at the electrochemical oxidation was investigated evaluating the decolorization and the chemical oxygen demand (COD) removal at optimal conditions. Complete decolorization of RhB was achieved in the presence of chloride ions at different times using both electrodes. An optimum efficiency was obtained at $\mathrm{pH} 6.5, \mathrm{~T}=25^{\circ} \mathrm{C}$. Also, the current density of $40 \mathrm{~mA} \mathrm{~cm}^{-2}$ using the DSA electrode in $\mathrm{NaCl} 0.05 \mathrm{~mol} \mathrm{~L}^{-1}+\mathrm{Na}_{2} \mathrm{SO}_{4} 0.1 \mathrm{~mol} \mathrm{~L}^{-1}$ mixture solution as a supporting electrolyte, $100 \%$ color removal and $61.7 \%$ chemical oxygen demand removal after $90 \mathrm{~min}$ of electrolysis were achieved. DSA showed better performance than $\mathrm{SnO}_{2}$ in wide operating conditions and was proved to be more cost-effective and more efficient. The effectiveness of the degradation is explained by indirect electrochemical oxidation, where in the presence of chlorides electrolyte leads to the electro-generation of strong oxidant species, such as $\mathrm{Cl}_{2}$ and $\mathrm{ClO}^{-}$ions, improving the efficiency of treatment at both electrodes.
\end{abstract}

\section{Introduction}

Surface water contamination by wastewater from paper and textile industries are greatly colored due to the existence of dyes and harmful compounds. Textile and printing industries are important causes of water pollution in developing countries, since its discharged wastewater could not only contain persistent organic dyes but also toxic byproducts. Residual dyestuffs are characterized by a strong color, high organic content and stable chemical structure due to the presence of azo functional groups. Therefore, they have affected serious menaces for environmental pollution $[1,2]$. Various methods are commonly used to dye removal from wastewater such as biological degradation method [3], adsorption [4,5], coagulation-flocculation [6], Fenton's oxidation [7], membrane separation [8] and ozonation [9]. The literature also recommended the use of electrochemical processes as an advanced alternative for removing dyes from colored effluents [10-14]. The electrochemical treatment is commonly based on the elimination of pollutants directly on the anode surface, via production of $\mathrm{OH}$ - [15-17], or/ and other oxidants such as chlorine, persulfate, and others. It has been demonstrated that the anode material plays an essential part in the electro-degradation of organic pollutants. Various materials have been tested and assessed for dye removal from effluents. The dimensionally stable anode (DSA ${ }^{\circ}$ ) is made of a titanium base metal covered with a thin conducting ruthenium or iridium oxide. The DSA anode exhibits the high chemical and electrochemical stability even at high current densities, longer operating lifetime, commercially available and comparatively low cost $[18,19]$. These anodes are mainly used in the presence of $\mathrm{Cl}^{-}$to produce active chlorine oxidants $\left(\mathrm{Cl}_{2}, \mathrm{HOCl}\right.$ and $\left.\mathrm{OCl}^{-}\right)$ via the following equations:

$$
\begin{aligned}
& 2 \mathrm{Cl}^{-} \rightarrow \mathrm{Cl}_{2}+2 \mathrm{e}^{-} \\
& \mathrm{Cl}_{2}+\mathrm{H}_{2} \mathrm{O} \rightarrow \mathrm{HClO}+\mathrm{H}^{+}+\mathrm{Cl}^{-}
\end{aligned}
$$

The concentration of the weak acid: $\mathrm{HOCl}$ and its conjugate base $\mathrm{OCl}^{-}$depends on the $\mathrm{pH}$ solution:

$\mathrm{HClO} \leftrightarrows \mathrm{OCl}^{-}+\mathrm{H}^{+}$

The DSA has been classified as 'active' or 'non-active' depending on

\footnotetext{
* Corresponding author.

E-mail address: brahim.elibrahimi@edu.uiz.ac.ma (B. El Ibrahimi).
} 
the electrode nature [20]. The active electrodes type mediate oxidation of organic compounds by the formation of metal oxide $\left(\mathrm{MO}_{\mathrm{x}}{ }^{+1}\right)$, where the highest state of oxidation available leads to selective oxidation (e.g., $\mathrm{IrO}_{2}$ or $\mathrm{RuO}_{2}$ ). In the case of non-active electrodes, there is no higher oxidation state existing and the organic compounds are oxidized directly by an adsorbed $\mathrm{OH} \cdot$, which gives a complete mineralization. The $\mathrm{SnO}_{2}$ electrode is a promising non-active anode material, which exhibits a high over-potential for the oxygen evolution reaction and a large accumulation of hydroxyl radicals on its surface. However, $\mathrm{SnO}_{2}$ has a short lifetime and improvements are necessary to make it suitable for that purpose [21,22].

In the last years, several papers have compared the treatment of some wastewater containing dye with active chlorine produced at DSA type anodes. The addition of $\mathrm{NaCl}$ as supporting electrolyte in the wastewater improves the oxidation capacity of DSA electrodes [23]. In comparison to other electrodes, DSAs have high chemical and mechanical, and higher current density. Many workers have been used DSA as an efficient material for degradation of glyphosate formulations [24], Reactive Blue 4 [25], Methyl orange [26] and mixtures of phenol-formaldehyde [27]. In these studies, the efficiency depended on several parameters, like pollutant concentration, initial $\mathrm{pH}$, supporting electrolyte, cathode material, current density and temperature.

The application of these anode materials has been proposed due to the electro-catalytic features to produce the in-situ strong oxidant species, mainly active chloride. For our best knowledge, there is not yet a comparative study on the electro-degradation by using DSA and tin oxide $\left(\mathrm{SnO}_{2}\right)$ anode. In addition, the Rhodamine $\mathrm{B}$ dye was poorly studied as a target pollutant for the electro-degradation process. For this purpose, it is chosen as a pollutant to carry out this comparing study.

Thus, the aim of this paper is to compare the electrochemical oxidation of the Rhodamine $\mathrm{B}$ dye (RhB) on DSA and $\mathrm{SnO}_{2}$ electrodes as an active and non-active model of electrode. The effect of the main operating parameters, such as current density, $\mathrm{pH}_{0}$, electrolyte support and temperature on color removal are investigated to determine the optimum conditions for each electrode.

\section{Experiment}

\subsection{Chemicals compounds}

The chemicals were of the highest purity grade and were employed without any treatment. $\mathrm{H}_{2} \mathrm{SO}_{4}, \mathrm{Na}_{2} \mathrm{SO}_{4}$ and $\mathrm{NaCl}$ were of analytical grade with purity level $>98 \%$ from Sigma-Aldrich. The dyestuff solution containing Rhodamine B used without any further purification (Table 1 ) was prepared by dissolving the dye $\left([\mathrm{RhB}]=50 \mathrm{mg} \mathrm{L}^{-1}\right)$ in distilled water containing a suitable amount of the chosen supporting electrolyte $\left(\mathrm{NaCl}\right.$ and $\mathrm{Na}_{2} \mathrm{SO}_{4}$ ).

\subsection{Electro-oxidation experiments}

The electrolysis was performed in a conventional three-electrode cell $(100 \mathrm{~mL})$ using a computer controlled with VersaSTAT 3 potentiostat/galvanostat. The dimensionally stable anodes, DSA (De Nora Company) and the commercial electrode $\mathrm{SnO}_{2}$ (ESC International Company) were used as working electrodes, while saturated calomel (SCE) was used as a reference electrode and a Pt plate was used as the auxiliary electrode. The inter-electrode distance was fixed at approximately $1 \mathrm{~cm}$. The exposed apparent area of the working electrodes was $1 \mathrm{~cm}^{2}$. The solution was stored in a $100 \mathrm{~mL}$ thermoregulated glass reservoir containing $50 \mathrm{mg} \mathrm{L}^{-1}(\mathrm{RhB})$ with an electrolyte support $\left(\mathrm{Na}_{2} \mathrm{SO}_{4}\right.$ and $\left.\mathrm{NaCl}\right)$. The solutions were stirred by a magnetic stirrer under constant rotation speed. For stabilizing the electrode surface and to obtain reproducible results, the electrodes were pre-treated by means of anodic polarization in $0.5 \mathrm{~mol} \mathrm{~L}^{-1} \mathrm{H}_{2} \mathrm{SO}_{4}$ at $30 \mathrm{~mA} \mathrm{~cm}^{-2}$ for $10 \mathrm{~min}$ before each experiment.

\subsection{Analytical methods}

During the electrolysis, the sample solutions were withdrawn from the cell at regular intervals conveniently analyzed. The absorbance of the solution was determined spectrophotometrically on the model 6800 UV-visible spectrophotometer Jenway at the maximum visible wavelength using $1 \mathrm{~cm}$ path-length cells. The percentage dye decolorization was calculated from the expression:

$\%$ Color Removal $=\frac{A_{0}-A_{t}}{A_{0}} \times 100$

Where: $\mathrm{A}_{0}$ and $\mathrm{A}_{\mathrm{t}}$ are the absorbance at an initial time and time $t$ for $\lambda_{\text {max }}=554 \mathrm{~nm}$, respectively.

The chemical oxygen demand (COD) was determined using a digester (Lovibond RD 125) and a colorimeter (Lovibond Checkit direct COD VARIO, Germany), the percentage of COD removal value was calculated as follows:

$\% C O D=\frac{C O D_{i}-C O D_{t}}{C O D_{i}} \times 100$

Where $\operatorname{COD}_{\mathrm{i}}$ and $\mathrm{COD}_{\mathrm{t}}$ are the values of $\mathrm{COD}\left(\mathrm{mg} \mathrm{L}^{-1}\right.$ of $\left.\mathrm{O}_{2}\right)$ at an initial

Table 1

Molecular structure of Rhodamine B dye and its chemical properties.

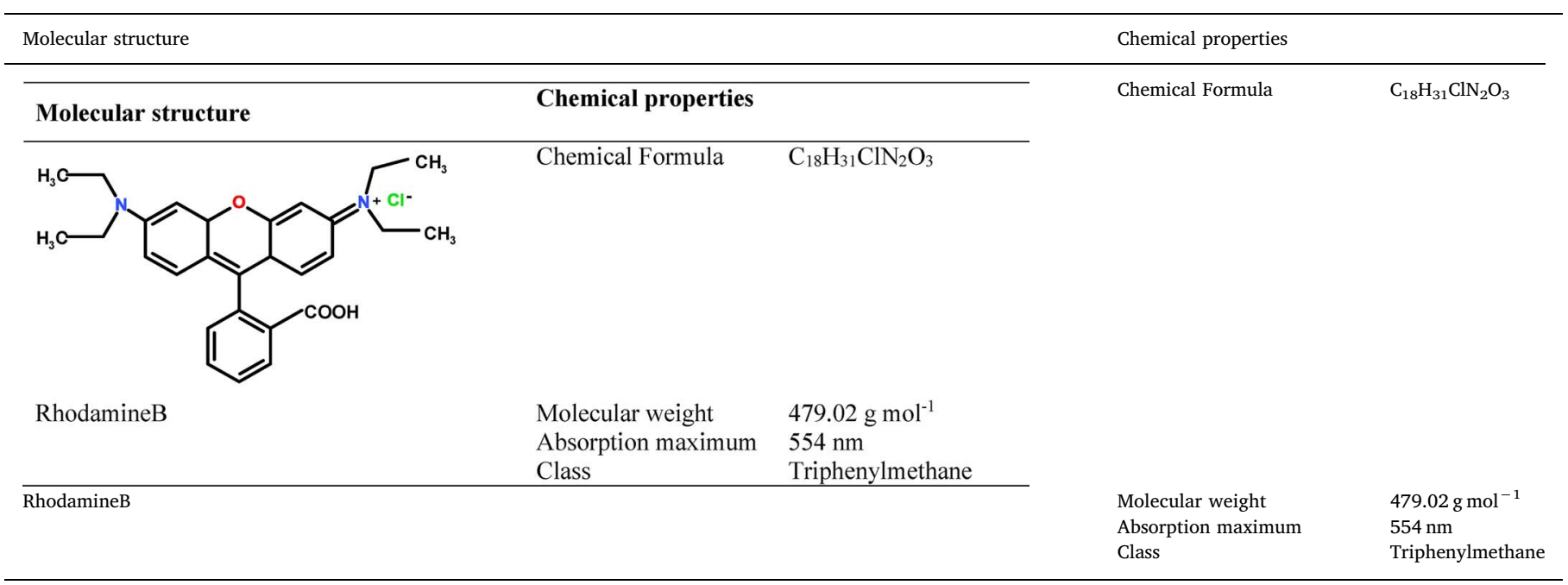




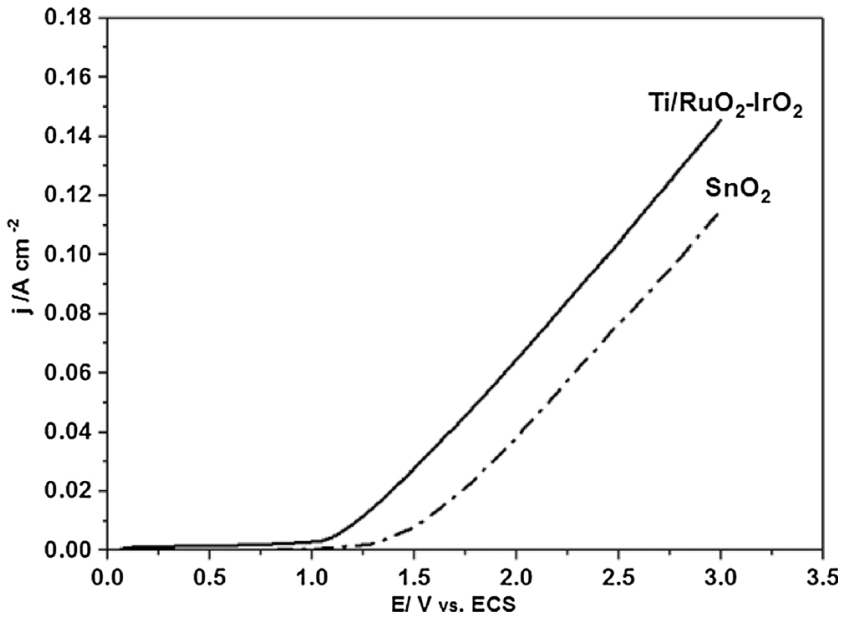

Fig. 1. Linear polarization curves recorded in $0.1 \mathrm{~mol} \mathrm{~L}^{-1} \mathrm{Na}_{2} \mathrm{SO}_{4}$ at $25^{\circ} \mathrm{C}$ using a scan rate of $50 \mathrm{mV} \mathrm{s}^{-1}$. The reference electrode was SCE and the counter-electrode was Pt.

time and at time " $t$ ", respectively.

\section{Results and discussion}

\subsection{Voltammetric characterization}

Fig. 1 shows linear polarization curves of $\mathrm{Ti} / \mathrm{RuO}_{2}-\mathrm{IrO}_{2}$ (DSA) and $\mathrm{SnO}_{2}$ electrodes obtained in $0.5 \mathrm{~mol} \mathrm{~L}^{-1} \mathrm{Na}_{2} \mathrm{SO}_{4}$ with a scan rate of $50 \mathrm{mV} \mathrm{s}^{-1}$. In general, anodic oxygen evolution is a competitive reaction in the anodic oxidation of pollutants since it causes power loss. In addition, there is a formation of bubbles on the surface of the electrode, which can negatively influence the reactive area.

Based on the curve, the DSA electrode had a relatively high current response even under low potential and an increase with the applied potential until an onset potential of $1 \mathrm{~V} v s$ SCE for oxygen evolution over-potential and was consequently good electro-catalysts for the oxygen evolution reaction. While $\mathrm{SnO}_{2}$ electrode had almost no current response until the applied potential was higher than $1.4 \mathrm{~V}$ vs SCE. In addition, the $\mathrm{SnO}_{2}$ is a catalyst for oxygen evolution as well but not as DSA-because the difference in the current density, comparing to the DSA is small-and it is not to be effective for the hydroxyl radicals generation. This behavior indicates that the anode could prescribe good electro-catalytic properties for the degradation of the organic pollutants in solution due to a low adsorption of oxidizing species generated at the anode surface in the form of the hydroxyl radicals [28,29].

\subsection{Effect of current density}

Fig. 2 shows the effect of the applied current densities (range $20-40 \mathrm{~mA} \mathrm{~cm}^{-2}$ ) on color decay in accordance with the time during the electrolysis of the synthetic dye at $25^{\circ} \mathrm{C}$, using DSA (Fig. 2(a)) and $\mathrm{SnO}_{2}$ (Fig. 2(b)) anodes, respectively. During the electrolysis treatment of $\mathrm{RhB}\left(50 \mathrm{mg} \mathrm{L}^{-1}\right)$ in all cases, total decolorization occurred with both electrodes at $j=40 \mathrm{~mA} \mathrm{~cm}^{-2}$. The level of decolorization directly is related to the electrode nature and the applied current density, and that it could be carried out by both direct electro-oxidation. Although complete color removal was achieved for both used anodes, the rate dye removal was faster with the DSA electrode as compared with $\mathrm{SnO}_{2}$ electrode.

Decolorization time decreased with an increase in $j$ from 20 to $40 \mathrm{~mA} \mathrm{~cm}^{-2}$. It was found that the degradation of the RhB dye removal efficiencies increased (Fig. 2) on both electrodes with increasing the applied current densities due to the increased rate of production of oxidants, such as chlorine/hypochlorite at higher current densities. In the experimental conditions, the anodic oxidation of $\mathrm{RhB}$ occurs heterogeneously, and must be transported to the anode surface first, and then be oxidized there. The dye degradation may be controlled by the current or mass transfer [30].

At 20, 30 and $40 \mathrm{~mA} \mathrm{~cm}^{-2}$ using $\mathrm{SnO}_{2}$ electrode, $72.9 \%, 98.6 \%$ and $100 \%$ of color removal were achieved respectively (Fig. 2(a)) at $90 \mathrm{~min}$ of treatment. Under similar conditions, the color was almost completely removed on DSA anode after $40 \mathrm{~min}$ of treatment, while for the $\mathrm{SnO}_{2}$ electrode the removal ratio was less than $64 \%$. The color was eliminated for all the applied current intensities in different times of electrolysis (Fig. 2(b)). Consequently, the rate of RhB electro-degradation reaction depends on the current densities applied.

\subsection{Effect of electrolyte support}

Fig. 3 displays the decolorization efficiency using two supporting electrolytes $\left(\mathrm{Na}_{2} \mathrm{SO}_{4}\right.$ and $\left.\mathrm{NaCl}\right)$ and their concentration on decolorization efficiency on both electrodes. The $\mathrm{NaCl}$ concentration strongly influences the rate of color and organic removal.

It can be observed from Fig. 3 that the decolorization rate of dye during the electrochemical degradation is much better when $\mathrm{NaCl}$ is added to the supporting electrolyte for both electrodes due to the reactions between the generated species chlorine/hypochlorite and the dye molecules. This observation can be attributed to the electro-oxidation by active chlorine, where direct anodic oxidation of $\mathrm{Cl}^{-}$ion present in the solution leads to in-situ production of chlorine $\left(\mathrm{Cl}_{2}\right)$ at the anode and then formation of dissolved free chlorine species, which contributes to a better efficiency in the degradation of the dye in solution and other organic substances (Eqs. (1)-(3). The indirect electrochemical action implicates the application of an electrical current to the wastewater containing chloride ions to transform it to chlorine/ hypochlorite.

Szpyrkowicz et al. [31] reported a study on three dyes degradation at $\mathrm{pH}=2$ in presence of $\mathrm{NaCl}(0.1 \mathrm{M})$ as supporting electrolyte and $\mathrm{T}=25^{\circ} \mathrm{C}$. The color removal with different electrode combination was found in the following order: $\mathrm{Ti} / \mathrm{MnO}_{2}-\mathrm{RuO}_{2}>\mathrm{Ti} / \mathrm{RuO}_{2}-\mathrm{TiO}_{2}$. In another study, Mohan et al. [32,33] found that the removal of acid brown 14 dye using three different electrodes in presence of $0.01 \mathrm{M} \mathrm{NaCl}$ at $\mathrm{pH}=7$ followed the sequence: $\mathrm{Ti} / \mathrm{TiO}_{2}-\mathrm{RuO}_{2}>\mathrm{Ti} / \mathrm{TiO}_{2}-\mathrm{SnO}_{2}>\mathrm{Ti} /$ $\mathrm{TiO}_{2}-\mathrm{RuO}_{2}-\mathrm{PbO}_{2}$.

Fig. 3 shows that, on both electrolytes, the decolorization on DSA performed much better than that on $\mathrm{SnO}_{2}$ electrode in the presence of chloride at different concentration. Color removal on the DSA electrode increased from about $19.6 \%$ in the $\mathrm{Na}_{2} \mathrm{SO}_{4}$ electrolyte to almost $100 \%$ in $\mathrm{NaCl}$ medium after one hour. Similarly, on the $\mathrm{SnO}_{2}$ electrode, the color removal increased from about $14.3 \%$ to $90.3 \%$. The concentration of RhB declined exponentially with time and the degradation rate could be expressed by the equation 6 , in literature, the decolorization behavior was found to fit well the pseudo-first order kinetics [2,34].

$\operatorname{Ln}\left(\frac{C_{0}}{C_{t}}\right)=k_{a p p} t$

Where, $\mathrm{C}_{0}$ and $\mathrm{C}_{\mathrm{t}}$ are the dye concentration $\left(\mathrm{mg} \mathrm{L}^{-1}\right)$ of the solution dye at the beginning and at time $t$, respectively, and $\mathrm{k}_{\text {app }}\left(\mathrm{min}^{-1}\right)$ is the apparent observed rate constant. As the correlation coefficient values shown in Table 2, the decolorization at different concentration of $\mathrm{NaCl}$ on both electrodes were found to fit this kinetics model. The apparent rate constants $\mathrm{k}_{\mathrm{app}}$ reported in Table 2 is calculated from the plot slope of $\ln \left(\mathrm{C}_{0} / \mathrm{C}_{\mathrm{t}}\right)$ (Eq. (6)), and shows that the quickest $\mathrm{RhB}$ removal was achieved by anodic oxidation with DSA within $0.079 \mathrm{~min}^{-1}$ at $40 \mathrm{~mA} \mathrm{~cm}^{-2}$ current density, but on $\mathrm{SnO}_{2}$ anode in the same condition is $0.04 \mathrm{~min}^{-1}$.

\subsection{Effect of initial $p H$}

$\mathrm{pH}$ is a very important factor for wastewater treatment during the 


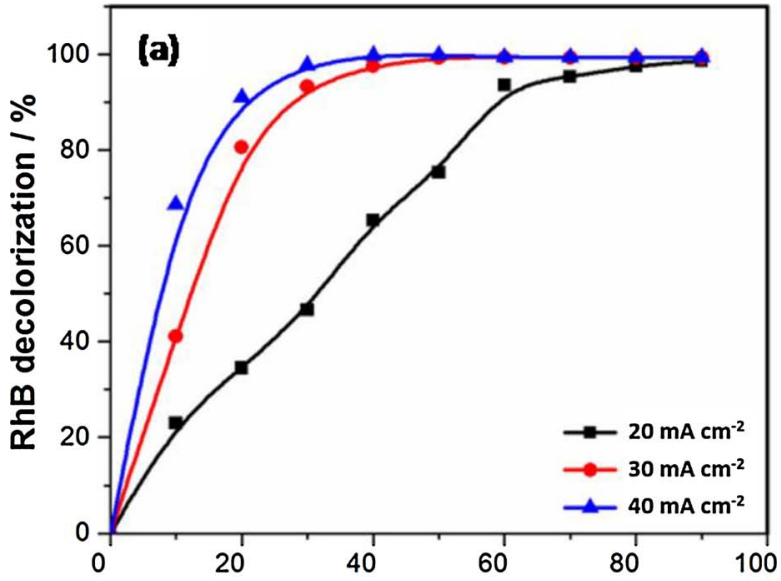

Time / min

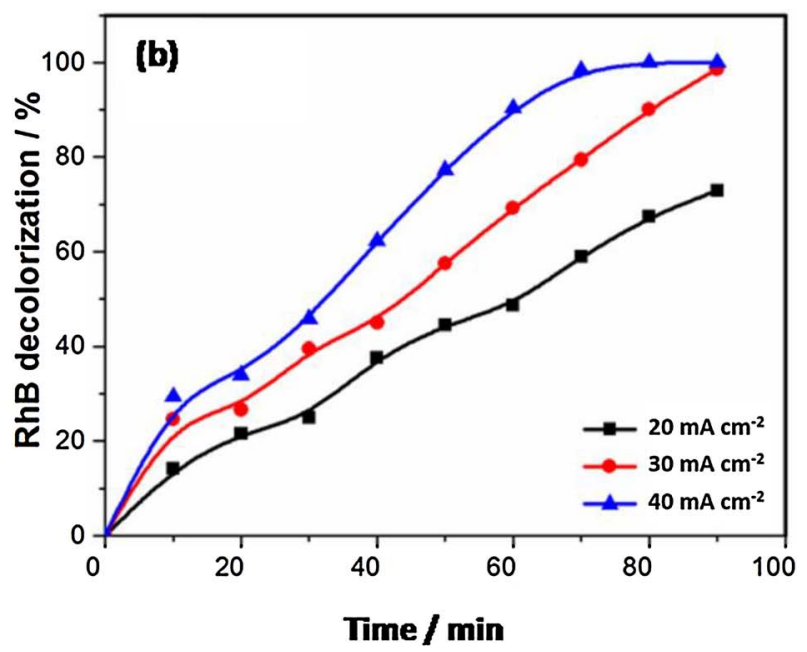

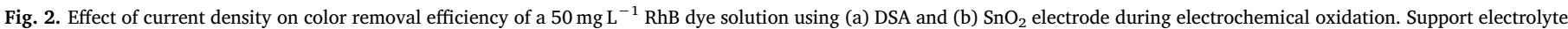
was $0.1 \mathrm{~mol} \mathrm{~L}^{-1} \mathrm{Na}_{2} \mathrm{SO}_{4}+0.05 \mathrm{~mol} \mathrm{~L}^{-1} \mathrm{NaCl}$, under $\mathrm{pH} 6.5$ at $25^{\circ} \mathrm{C}$.

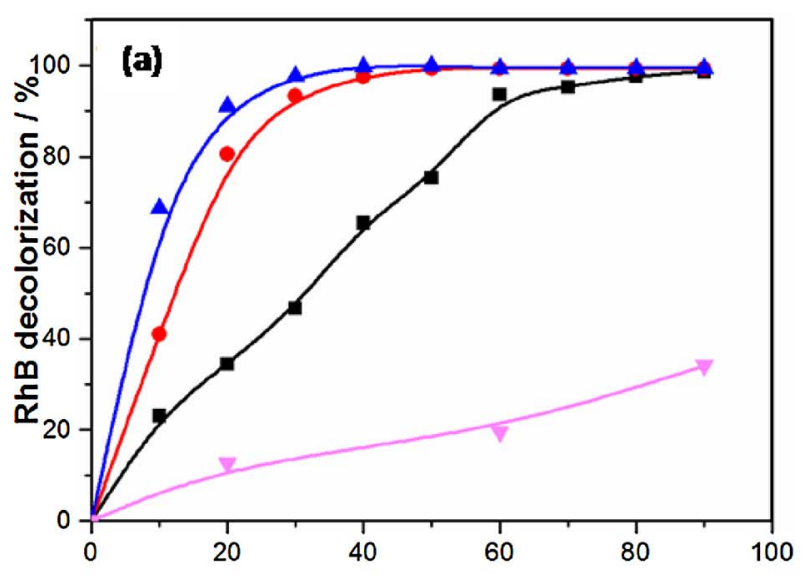

Time / min

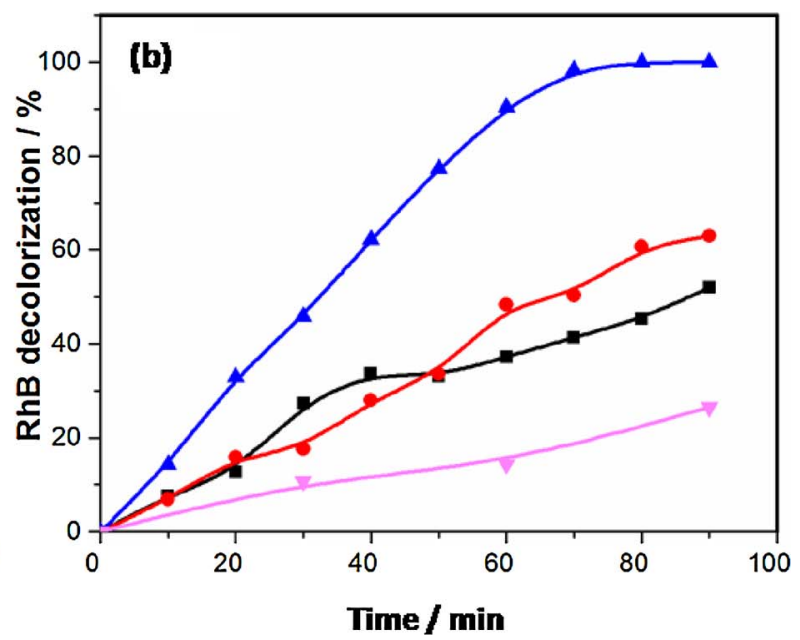

Fig. 3. Effect of electrolytes on color removal of $50 \mathrm{mg} \mathrm{L}^{-1} \mathrm{RhB}$ solution, using (a) DSA and (b) $\mathrm{SnO}_{2},(\boldsymbol{\nabla}) 0.1 \mathrm{~mol} \mathrm{~L}^{-1} \mathrm{Na}_{2} \mathrm{SO}_{4}$; $(\boldsymbol{\square}) 0.1 \mathrm{~mol} \mathrm{~L}^{-1} \mathrm{Na}_{2} \mathrm{SO}_{4}+0.01 \mathrm{~mol} \mathrm{~L}^{-1} \mathrm{NaCl}$; $\left({ }^{2}\right)$

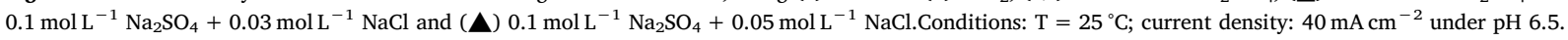

Table 2

Energy per order of treated RhB solution, calculated from Eq. (7), and apparent constant during oxidation at DSA and $\mathrm{SnO}_{2}$ electrodes for different applied current densities and temperature in $100 \mathrm{~mL}$ dye solution. $[\mathrm{RhB}]_{0}=50 \mathrm{mg} \mathrm{L}^{-1}$, Electrolyte $=0.1 \mathrm{~mol} \mathrm{~L}^{-1}$ $\mathrm{Na}_{2} \mathrm{SO}_{4}+0.05 \mathrm{~mol} \mathrm{~L}^{-1} \mathrm{NaCl}$.

\begin{tabular}{|c|c|c|c|c|}
\hline Parameters & $\mathrm{R}$ & $\mathrm{k}_{\mathrm{app}}\left(\min ^{-1}\right)$ & $\begin{array}{l}\text { Average cell } \\
\text { voltage (V) }\end{array}$ & $\begin{array}{l}\text { Energy }\left(\mathrm{kW} \mathrm{h} \mathrm{m}^{-3}\right. \\
\left.\text { ordre }^{-1}\right)\end{array}$ \\
\hline \multicolumn{5}{|l|}{ DSA $^{a}$} \\
\hline $20 \mathrm{~mA} \mathrm{~cm}^{-2}$ & 0.86 & 0.042 & 2.7 & 8.229 \\
\hline $30 \mathrm{~mA} \mathrm{~cm}^{-2}$ & 0.95 & 0.070 & 2.8 & 7.680 \\
\hline $40 \mathrm{~mA} \mathrm{~cm}^{-2}$ & 0.96 & 0.079 & 2.9 & 9.397 \\
\hline \multicolumn{5}{|l|}{ Temperature $^{\mathrm{b}}$} \\
\hline $25^{\circ} \mathrm{C}$ & 0.89 & 0.079 & 2.7 & 8.749 \\
\hline $30^{\circ} \mathrm{C}$ & 0.93 & 0.049 & 2.6 & 13.584 \\
\hline $35^{\circ} \mathrm{C}$ & 0.96 & 0.079 & 2.3 & 7.453 \\
\hline \multicolumn{5}{|l|}{$\mathrm{SnO}_{2}{ }^{\mathrm{a}}$} \\
\hline $20 \mathrm{~mA} \mathrm{~cm}^{-2}$ & 0.84 & 0.012 & 2.2 & 23.467 \\
\hline $30 \mathrm{~mA} \mathrm{~cm}^{-2}$ & 0.87 & 0.029 & 2.4 & 15.890 \\
\hline $40 \mathrm{~mA} \mathrm{~cm}^{-2}$ & 0.92 & 0.040 & 2.5 & 16.000 \\
\hline \multicolumn{5}{|l|}{ Temperature ${ }^{b}$} \\
\hline $25^{\circ} \mathrm{C}$ & 0.86 & 0.041 & 2.2 & 13.737 \\
\hline $30^{\circ} \mathrm{C}$ & 0.91 & 0.034 & 2.0 & 15.059 \\
\hline $35^{\circ} \mathrm{C}$ & 0.89 & 0.040 & 1.9 & 12.160 \\
\hline
\end{tabular}

a $\mathrm{T}=25^{\circ} \mathrm{C}$.

b $j=40 \mathrm{~mA} \mathrm{~cm}^{-2}$. anodic oxidation. There are several reports on the effect of $\mathrm{pH}$, nevertheless the results are dissimilar and even opposing due to different organic molecules and electrode material [30,35,36]. Anodic oxidation experiments were done within the $\mathrm{pH}$ range of 3-9 and Fig. 4 shows the decolorization efficiency under different $\mathrm{pH}$ values. The color of $\mathrm{RhB}$ solution depends upon the concentration of $\mathrm{H}^{+}$and $\mathrm{HO}^{-}$ions.

The color removal efficiencies were higher in neutral $\mathrm{pH}(6.5)$ and acid $\mathrm{pH}$ (3) when compared to alkaline conditions with both electrodes. In the case of $\mathrm{SnO}_{2}$ anode, when the $\mathrm{pH}$ of the solutions was adjusted to 9, more hydroxyl radicals in the system were gathered at the anode surface and competed with the anode materials to produce oxygen, resulting in a degradation effect decrease [37]. However, for DSA electrode, total decolorization was achieved after $40 \mathrm{~min}(\mathrm{pH}=3$ and $\mathrm{pH}=6.5$ ) due to the main reaction of indirect chlorine oxidation, since this type of anode was capable of efficient formation of $\mathrm{HOCl}$ and $\mathrm{Cl}_{2}$ species in acidic solution resulted in the best removal rates. This can be attributed to the higher standard potential of $\mathrm{Cl}_{2}$ and $\mathrm{HClO}$ than $\mathrm{ClO}^{-}$. Furthermore, the order of the species formation at various $\mathrm{pH}$ ranges is as follows: $\mathrm{ClO}^{-}(\mathrm{pH}>8)>\mathrm{HClO}(8>\mathrm{pH}>3)>\mathrm{Cl}_{2}$ (aq) $(\mathrm{pH} \sim 3)$ [38,39].

In alkaline medium, $\mathrm{ClO}^{-}$ions are possibly present with greater concentration than other chlorine species. The removal of the dye decreases in alkaline medium, which can be attributed to the low oxidation potential of $\mathrm{ClO}^{-}$species compared with $\mathrm{Cl}_{2}$ and $\mathrm{HOCl}$. As 

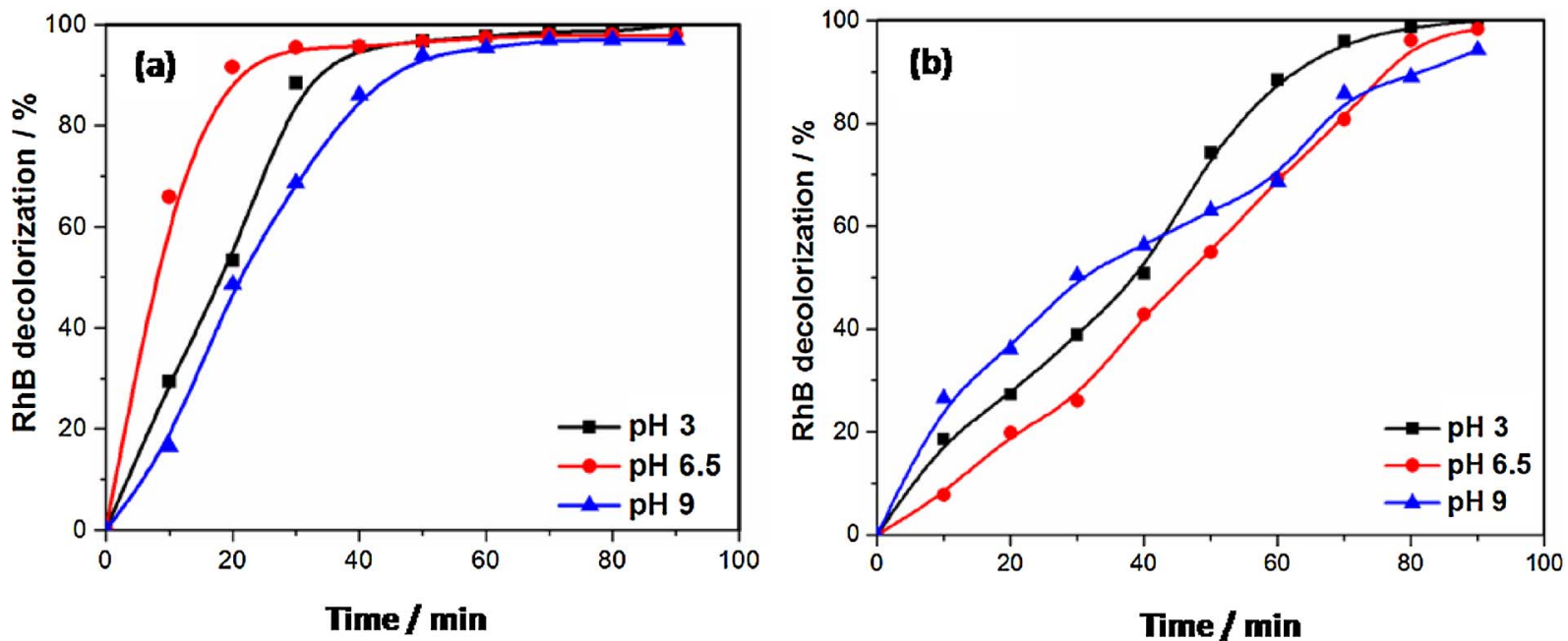

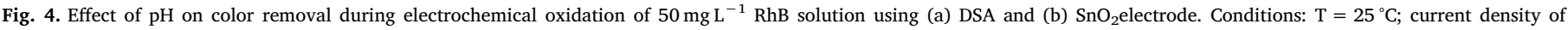
$40 \mathrm{~mA} \mathrm{~cm}^{-2}$; electrolyte $\left(\mathrm{Na}_{2} \mathrm{SO}_{4}=0.1 \mathrm{~mol} \mathrm{~L}^{-1}+\mathrm{NaCl}=0.05 \mathrm{~mol} \mathrm{~L}^{-1}\right)$.

reported by Prasad et al. [40], in alkaline medium, the hypochlorous acid was converted to $\mathrm{ClO}_{4}{ }^{-}$and $\mathrm{ClO}_{3}{ }^{-}$species and as a consequence decolorization rate was decreased. The formation of $\mathrm{ClO}_{4}{ }^{-}$and $\mathrm{ClO}_{3}{ }^{-}$ species is likely to occur during the electrolysis process using this anode type (i.e. DSA), but their low concentration might be attributed to the competition between the reactions of chloride oxidation and oxygen evolution. Possibly the powerful species oxidants get formed in acidic $\mathrm{pH}$ range. In addition, the active chlorine generation is controlled by the solution $\mathrm{pH}$ via Eq. (3). Regardless of the initial $\mathrm{pH}$ values, the color removal efficiency was higher by DSA electrode than the $\mathrm{SnO}_{2}$ electrodes.

\subsection{Effect of temperature}

The variation of color removal and RhB concentration throughout the electrolysis treatment at 25,30 and $35^{\circ} \mathrm{C}$ when applying a current density of $40 \mathrm{~mA} \mathrm{~cm}^{-2}$ is shown in Fig. 5. As can be seen, the temperature increase has a little effect on the color removal efficiency of the solution. Furthermore, the total color removal was achieved with both DSA and $\mathrm{SnO}_{2}$ anode materials. A possible enhancement of decolorization efficiency of $\mathrm{RhB}$ could be attributed to the improvement of the charge transfer rate and the rate reaction of the active chlorine with $\mathrm{RhB}$ in the bulk solution. Nevertheless, these effects are counterbalanced by decomposition reactions of the oxidants, as indicated in the

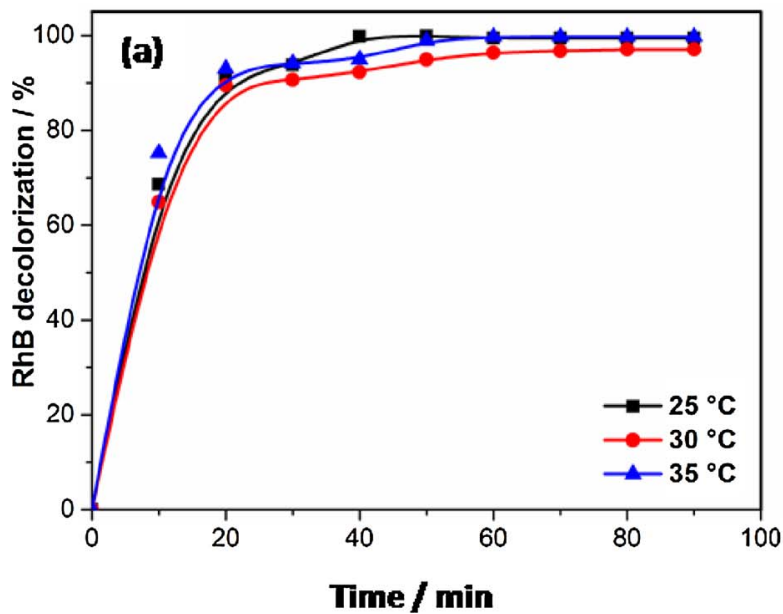

work of Panizza et al. [41], also with the loss of chloro-oxidant species in the gaseous phase under acidic conditions (mostly hypochlorous acid $\mathrm{HOCl}_{(\mathrm{g})}$ ).

The small difference between the results obtained at different temperatures is only due to an increase of the diffusion rate with increasing temperature owing to the decrease of the medium viscosity [42]. Temperatures values changes had slight influence on the degradation of RhB dye by hydroxyl radicals, since similar removal percentages were attained. This can be explained by the raise in the chemical reactions rates, which is in agreement with the results reported by Tavares et al. [43], and maybe due to the self-decomposition of the active chlorine [44]. While, the values of the apparent first order kinetic constants remained very close for the temperature levels investigated. Thus, the working temperature selected for further experiments was $25{ }^{\circ} \mathrm{C}$.

\subsection{Comparison between $\mathrm{SnO}_{2}$ and DSA electrodes}

Fig. 6 shows the comparison of the trend of the COD and color removal during the electro-degradation of $\mathrm{RhB}$ on $\mathrm{SnO}_{2}$ and DSA electrodes. DSA anode provided an oxidation rate and a current efficiency that is higher than $\mathrm{SnO}_{2}$ in the same operating condition $\left(j=40 \mathrm{~mA} \mathrm{~cm}^{-2}, \mathrm{pH}_{\mathrm{i}}=3,[\mathrm{RhB}]=50 \mathrm{mg} \mathrm{L}^{-1}\right.$ and $\left.\mathrm{T}=25^{\circ} \mathrm{C}\right)$. After $3 \mathrm{~h}$ of electrolysis on a DSA, the COD value was $92.4 \%$ very close to

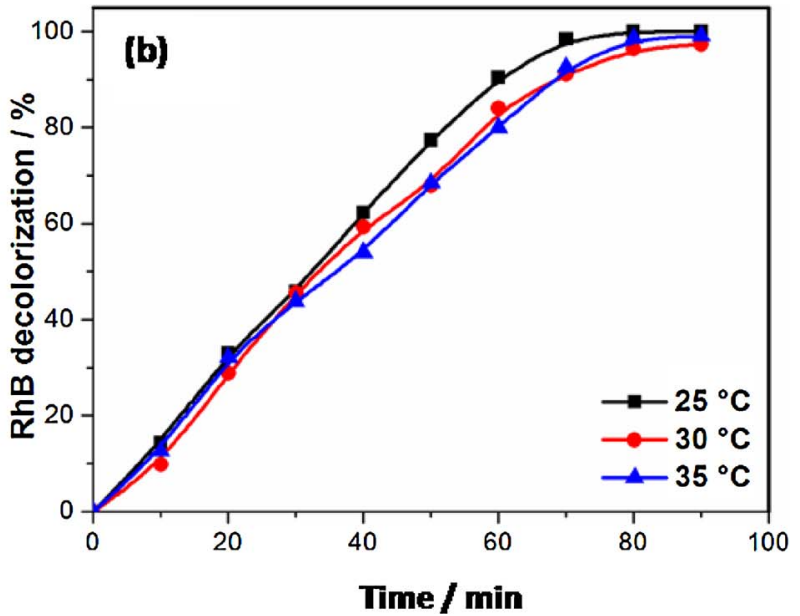

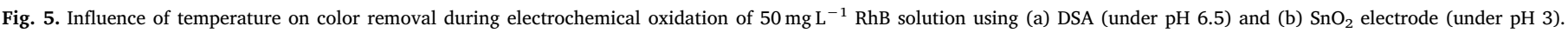
Operating conditions: $0.1 \mathrm{~mol} \mathrm{~L}^{-1} \mathrm{Na}_{2} \mathrm{SO}_{4}+0.05 \mathrm{~mol} \mathrm{~L}^{-1} \mathrm{NaCl}$ electrolyte, and current density of $40 \mathrm{~mA} \mathrm{~cm}^{-2}$. 

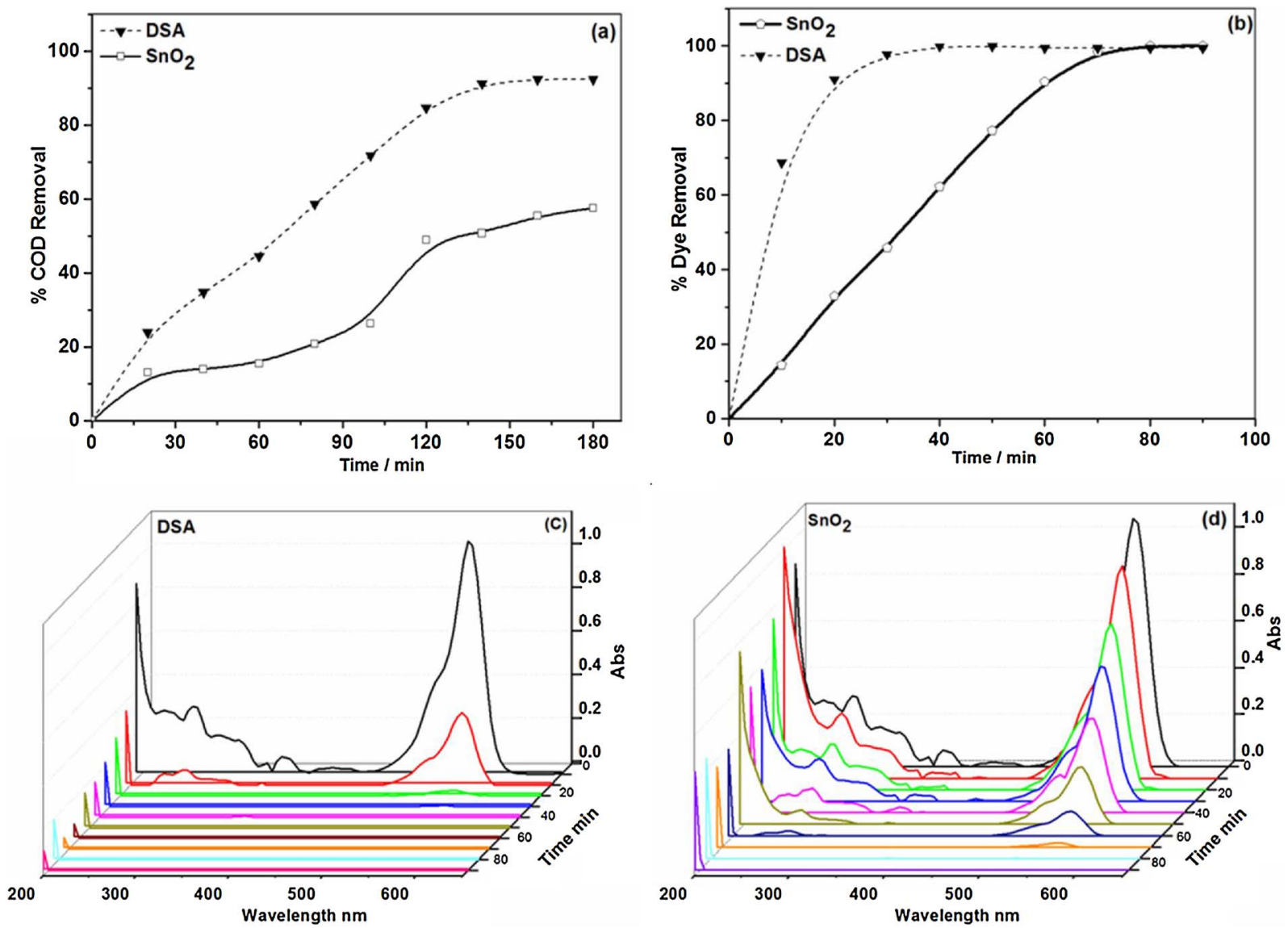

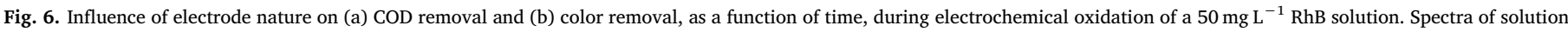

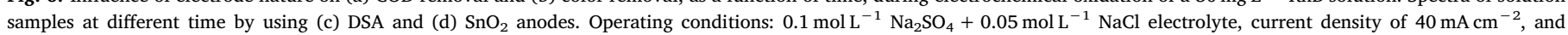
$\mathrm{T}=25^{\circ} \mathrm{C}$.

$100 \%$. Under the same conditions, the $\mathrm{SnO}_{2}$ anode hardly achieved $57.6 \%$. The presence of chloride is one of the best attractive media in the area of indirect oxidation. The great difference in COD removal rate can be explained by the quantity of $\mathrm{Cl}_{2}$ evolution on the both electrodes. So far as it is known, the DSA electrodes are very active for chlorine evolution and have a higher conductivity of the medium, which leads, in turn, to a faster reaction between the oxidant species and $\mathrm{RhB}$. The $\mathrm{Cl}_{2}$ in the solution results in the formation of reactive species such as $\left(\mathrm{HClO} / \mathrm{ClO}^{-}\right)$, as described elsewhere, and which is responsible for promoting faster compounds organic degradation [24].

The UV-vis spectrum of the RhB solution before and after degradation exhibited four bands, one in the visible region $(\sim 554 \mathrm{~nm})$ that is associated with color removal and three bands $(\sim 350,305$ and $255 \mathrm{~nm}$ ) in the UV-visible region are associated with $\pi-\pi^{*}$ transitions in aromatic moieties [45]. The Fig. 6(c) and (d) shows the spectrum of the electrolyte solution plotted as a function of the time electrolysis by applying $20 \mathrm{~mA} \mathrm{~cm}^{-2}$ as a current density with the both electrodes. At the beginning of the electrolysis, a continuous and synchronous decrease in band intensity could be observed with both electrodes, which resulted in a decay in the maximum absorbance of $99 \%$ after $30 \mathrm{~min}$ of degradation for DSA. In contrast, a $62.3 \%$ decay in absorbance at this wavelength was achieved in the same degradation time on the $\mathrm{SnO}_{2}$ electrode, indicating that DSA is more suitable for the degradation of wastewater containing dye RhB.

Electrical energy efficiency is one of the key factors in determining the feasibility of the electrochemical removal of organic compounds from wastewaters. Since the degradation of RhB followed pseudo-firstorder kinetics, the appropriate figure of merit was energy per order, noted $\mathrm{E}_{\mathrm{EO}}$, defined as the number of $\mathrm{kWh}$ of electrical energy required to reduce the concentration of contaminant in $1 \mathrm{~m}^{3}$ of water by one order of magnitude. The values of $\mathrm{E}_{\mathrm{EO}}\left(\mathrm{kWh} \mathrm{m}^{-3}\right.$ order $\left.^{-1}\right)$ can be calculated from the following equation [46]:

$E_{E O}=\frac{38.4 \times P}{\mathrm{k}_{1}^{\prime} \times \mathrm{V}}$

Where $\mathrm{P}$ is the electrical power input $(\mathrm{kW}), \mathrm{V}$ is the solution volume $\left(\mathrm{m}^{3}\right)$, and $\mathrm{k}_{1}^{\prime}\left(\mathrm{s}^{-1}\right)$ is the pseudo-first order rate constant.

Table 2 presents the variation of the energy per order for the electrochemical degradation on $\mathrm{SnO}_{2}$ and DSA anodes. According to these results, it can be observed that the value of $E_{\mathrm{EO}}$ decreased when the DSA anode was employed. The value of $E_{\mathrm{EO}}$ is at least three times lower at $20 \mathrm{~mA} \mathrm{~cm}^{-2}$ for the DSA anode than for the $\mathrm{SnO}_{2}$ and down to two times lower at $40 \mathrm{~mA} \mathrm{~cm}^{-2}$. It can be observed that the lowest value of $E_{\mathrm{EO}}$ obtained is at $40 \mathrm{~mA} \mathrm{~cm}^{-2}$ at $\mathrm{T}=35^{\circ} \mathrm{C}$ using DSA anode. However, the value is not substantially changed (between 8.229 and $9.397 \mathrm{~kW} \mathrm{~h}$ $\mathrm{m}^{-3}$ order $^{-1}$ ) for 20 and $40 \mathrm{~mA} \mathrm{~cm}^{-2}$. The $\mathrm{E}_{\mathrm{EO}}$ values presented here demonstrate that the use of a DSA anode was energy savings against $\mathrm{SnO}_{2}$ anode.

\section{Conclusion}

Electrochemical oxidation of an aqueous solution of Rhodamine B (RhB) dye was investigated under different experimental conditions by using $\mathrm{Ti} / \mathrm{RuO}_{2}-\mathrm{IrO}_{2}$ (DSA) and $\mathrm{SnO}_{2}$ anodes. Our findings revealed that both anodes evidenced great oxidation abilities to treat synthetic solutions containing this dye. When the process was operated at $\mathrm{pH}$ of 6.5, at $25{ }^{\circ} \mathrm{C}$ and under a current density of $40 \mathrm{~mA} \mathrm{~cm}^{-2}$ on the DSA electrode and $\mathrm{NaCl}$ supporting electrolyte at $0.05 \mathrm{~mol} \mathrm{~L}^{-1}, 100 \%$ color removal and $61.7 \%$ COD removal after $90 \mathrm{~min}$ of electrolysis were achieved. The Rhodamine B decay reaction follows pseudo-first-order 
kinetics, and the rate constant increases with applied current at $\mathrm{SnO}_{2}$ anodes, whereas it is essentially independent of the current at DSA. In the other hand, under the same operating conditions for both electrodes, the oxidation rate of the DSA is greater than that of the $\mathrm{SnO}_{2}$ anode, which requiring a shorter time of electrolysis to reach completed decolorization of treated solution dye. The influence of applied current density, as a function of time, showed that the electro-generated species from the anodic oxidation of chloride ions play a significant role in the efficacy of the electrochemical process. Our results showed the applicability of electrochemical technology, which proposes, as an alternative for dye removal from textile wastewater, eliminating their strong color and mitigating their eco-toxicological consequences for the aquatic environment.

\section{Acknowledgement}

The authors gratefully acknowledge the professor Karine GROENEN-SERRANO (Laboratoire Genie Chimique de Toulouse, France) for $\mathrm{SnO}_{2}$ electrode.

\section{References}

[1] A. Gupta, A. Pal, C. Sahoo, Photocatalytic degradation of a mixture of Crystal Violet (Basic Violet 3) and Methyl Red dye in aqueous suspensions using $\mathrm{Ag}+$ doped $\mathrm{TiO}$ 2, Dyes Pigm. 69 (3) (2006) 224-232.

[2] X. Ma, M. Zhou, A comparative study of azo dye decolorization by electro-fenton in two common electrolytes, J. Chem. Technol. Biotechnol. 84 (10) (2009) 1544-1549.

[3] M. Kornaros, G. Lyberatos, Biological treatment of wastewaters from a dye manufacturing company using a trickling filter, J. Hazard. Mater. 136 (1) (2006) 95-102.

[4] A.Y. Sham, S.M. Notley, Adsorption of organic dyes from aqueous solutions using surfactant exfoliated graphene, J. Environ. Chem. Eng. 6 (1) (2018) 495-504.

[5] S. Bentahar, A. Dbik, M. El Khomri, N. El Messaoudi, A. Lacherai, Adsorption of methylene blue, crystal violet and congo red from binary and ternary systems with natural clay: kinetic, isotherm, and thermodynamic, J. Environ. Chem. Eng. 5 (6) (2017) 5921-5932.

[6] M. Khayet, A. Zahrim, N. Hilal, Modelling and optimization of coagulation of highly concentrated industrial grade leather dye by response surface methodology, Chem. Eng. J. 167 (1) (2011) 77-83.

[7] Jiang W-x, W. Zhang, Li B-j, J. Duan, Y. Lv, Liu W-d, Ying W-c, Combined fenton oxidation and biological activated carbon process for recycling of coking plant effluent, J. Hazard. Mater. 189 (1) (2011) 308-314.

[8] A. Zahrim, N. Hilal, Treatment of highly concentrated dye solution by coagulation/ flocculation-sand filtration and nanofiltration, Water Resour. Ind. 3 (2013) 23-34.

[9] X.-b. Zhang, W.-y. Dong, W. Yang, Decolorization efficiency and kinetics of typical reactive azo dye RR2 in the homogeneous Fe (II) catalyzed ozonation process, Chem. Eng. J. 233 (2013) 14-23.

[10] C.A. Martínez-Huitle, E. Brillas, Decontamination of wastewaters containing synthetic organic dyes by electrochemical methods: a general review, Appl. Catal. B: Environ. 87 (3) (2009) 105-145.

[11] M. Faouzi, P. Canizares, A. Gadri, J. Lobato, B. Nasr, R. Paz, M. Rodrigo, C. Saez, Advanced oxidation processes for the treatment of wastes polluted with azoic dyes, Electrochim. Acta 52 (1) (2006) 325-331.

[12] N. Bensalah, A. Bedoui, S. Chellam, A. Abdel-Wahab, Electro-fenton treatment of photographic processing wastewater, CLEAN-Soil Air Water 41 (7) (2013) 635-644.

[13] T. Coşkun, E. Debik, N.M. Demır, Operational cost comparison of several pretreatment techniques for OMW treatment, CLEAN-Soil Air Water 40 (1) (2012) 95-99.

[14] C. Indermuhle, M.J.M. de Vidales, C. Sáez, J. Robles, P. Cañizares, J.F. GarcíaReyes, A. Molina-Díaz, C. Comninellis, M.A. Rodrigo, Degradation of caffeine by conductive diamond electrochemical oxidation, Chemosphere 93 (9) (2013) 1720-1725.

[15] I. Sirés, E. Brillas, M.A. Oturan, M.A. Rodrigo, M. Panizza, Electrochemical advanced oxidation processes: today and tomorrow: a review, Environ. Sci. Pollut. Res. 21 (14) (2014) 8336-8367.

[16] J.H.B. Rocha, A.M.S. Solano, N.S. Fernandes, D.R. da Silva, J.M. Peralta-Hernandez, C.A. Martínez-Huitle, Electrochemical degradation of remazol red BR and novacron blue CD dyes using diamond electrode, Electrocatalysis 3 (1) (2012) 1-12.

[17] J.L. Nava, M.A. Quiroz, C.A. Martínez-Huitle, Electrochemical treatment of synthetic wastewaters containing alphazurine a dye: role of electrode material in the colour and COD removal, J. Mex. Chem. Soc. 52 (4) (2008) 249-255.

[18] S. Trasatti, Electrocatalysis: understanding the success of DSA ${ }^{\circ}$, Electrochim. Acta
45 (15) (2000) 2377-2385.

[19] D. Rajkumar, J. Guk Kim, K. Palanivelu, Indirect electrochemical oxidation of phenol in the presence of chloride for wastewater treatment, Chem. Eng. Technol. 28 (1) (2005) 98-105.

[20] G. Malpass, D. Miwa, S. Machado, A. Motheo, Decolourisation of real textile waste using electrochemical techniques: effect of electrode composition, J. Hazard. Mater. 156 (1) (2008) 170-177.

[21] C.R. Costa, C.M. Botta, E.L. Espindola, P. Olivi, Electrochemical treatment of tannery wastewater using DSA electrodes, J. Hazard. Mater. 153 (1-2) (2008) 616-627.

[22] F.H. Oliveira, M.E. Osugi, F.M. Paschoal, D. Profeti, P. Olivi, M.V.B. Zanoni, Electrochemical oxidation of an acid dye by active chlorine generated using $\mathrm{Ti} / \mathrm{Sn}$ (1- x) Ir x O 2 electrodes, J. Appl. Electrochem. 37 (5) (2007) 583-592.

[23] F. Zaviska, P. Drogui, J.-F. Blais, G. Mercier, In situ active chlorine generation for the treatment of dye-containing effluents, J. Appl. Electrochem. 39 (12) (2009) $2397-2408$.

[24] S.A. Neto, A. De Andrade, Electrochemical degradation of glyphosate formulations at DSA anodes in chloride medium: an AOX formation study, J. Appl. Electrochem. 39 (10) (2009) 1863.

[25] R.G.D. Silva, A.R.D. Andrade, Degradation of the dye reactive blue 4 by coupled photoassisted electrochemistry at DSA ${ }^{\circ}$-type electrode, J. Braz. Chem. Soc. 27 (5) (2016) 857-865.

[26] M. Zhou, H. Särkkä, M. Sillanpää, A comparative experimental study on methyl orange degradation by electrochemical oxidation on BDD and MMO electrodes, Sep. Purif. Technol. 78 (3) (2011) 290-297.

[27] A.L.T. Fornazari, G.R. Malpass, D.W. Miwa, A.J. Motheo, Application of electrochemical degradation of wastewater composed of mixtures of phenol-formaldehyde, Water Air Soil Pollut. 223 (8) (2012) 4895-4904.

[28] M. Panizza, G. Cerisola, Electrocatalytic materials for the electrochemical oxidation of synthetic dyes, Appl. Catal. B: Environ. 75 (1) (2007) 95-101.

[29] C. Martinez-Huitle, M. Panizza, Application of $\mathrm{PbO} 2$ anodes for wastewater treatment, Advances in Chemistry Research, Nova Science Publishers, Inc, New York, 2010 .

[30] X. Chen, G. Chen, Anodic oxidation of orange II on Ti/BDD electrode: variable effects, Sep. Purif. Technol. 48 (1) (2006) 45-49, http://dx.doi.org/10.1016/j. seppur.2005.07.024.

[31] L. Szpyrkowicz, C. Juzzolino, S.N. Kaul, S. Daniele, M.D. De Faveri, Electrochemical oxidation of dyeing baths bearing disperse dyes, Ind. Eng. Chem. Res. 39 (9) (2000) 3241-3248.

[32] N. Mohan, N. Balasubramanian, In situ electrocatalytic oxidation of acid violet 12 dye effluent, J. Hazard. Mater. 136 (2) (2006) 239-243.

[33] N. Mohan, N. Balasubramanian, C.A. Basha, Electrochemical oxidation of textile wastewater and its reuse, J. Hazard. Mater. 147 (1-2) (2007) 644-651.

[34] D. Rajkumar, J.G. Kim, Oxidation of various reactive dyes with in situ electrogenerated active chlorine for textile dyeing industry wastewater treatment, $\mathrm{J}$ Hazard. Mater. 136 (2) (2006) 203-212.

[35] G. Lissens, J. Pieters, M. Verhaege, L. Pinoy, W. Verstraete, Electrochemical degradation of surfactants by intermediates of water discharge at carbon-based electrodes, Electrochim. Acta 48 (12) (2003) 1655-1663.

[36] M. Zhou, Z. Wu, D. Wang, Electrocatalytic degradation of phenol in acidic and saline wastewater, J. Environ. Sci. Health Part A 37 (7) (2002) 1263-1275.

[37] W. Kong, B. Wang, H. Ma, L. Gu, Electrochemical treatment of anionic surfactants in synthetic wastewater with three-dimensional electrodes, J. Hazard. Mater. 137 (3) (2006) 1532-1537.

[38] S. Singh, S.L. Lo, V.C. Srivastava, A.D. Hiwarkar, Comparative study of electrochemical oxidation for dye degradation: parametric optimization and mechanism identification, J. Environ. Chem. Eng. 4 (3) (2016) 2911-2921.

[39] C. Boxall, G. Kelsall, Hypochlorite Electrogeneration. 2. Thermodynamics and Kinetic-model of the Anode Reaction Layer, (1992).

[40] R.K. Prasad, S. Srivastava, Electrochemical degradation of distillery spent wash using catalytic anode: factorial design of experiments, Chem. Eng. J. 146 (1) (2009) 22-29.

[41] M. Panizza, G. Cerisola, Removal of colour and COD from wastewater containing acid blue 22 by electrochemical oxidation, J. Hazard. Mater. 153 (1) (2008) 83-88.

[42] C.A. Martínez-Huitle, M.A. Quiroz, C. Comninellis, S. Ferro, A. De Battisti, Electrochemical incineration of chloranilic acid using $\mathrm{Ti} / \mathrm{IrO} 2, \mathrm{~Pb} / \mathrm{PbO} 2$ and $\mathrm{Si} /$ BDD electrodes, Electrochim. Acta 50 (4) (2004) 949-956.

[43] M.G. Tavares, L.V. da Silva, A.M.S. Solano, J. Tonholo, C.A. Martínez-Huitle, C.L. Zanta, Electrochemical oxidation of methyl red using Ti/Ru 0.3 ti $0.7 \mathrm{O} 2$ and Ti/Pt anodes, Chem. Eng. J. 204 (2012) 141-150.

[44] J.-S. Do, W.-C. Yeh, In situ degradation of formaldehyde with electrogenerated hypochlorite ion, J. Appl. Electrochem. 25 (5) (1995) 483-489.

[45] M. Zhou, J. He, Degradation of cationic red X-GRL by electrochemical oxidation on modified PbO2 electrode, J. Hazard. Mater. 153 (1) (2008) 357-363.

[46] J.R. Bolton, K.G. Bircher, W. Tumas, C.A. Tolman, Figures-of-merit for the technical development and application of advanced oxidation technologies for both electricand solar-driven systems (IUPAC Technical Report), Pure Appl. Chem. 73 (4) (2001) $627-637$. 